\title{
J.H.デ・フロート著『装飾デザインにおける三角形』の概要 および出版の意図と著者の構想について
ON OUTLINE OF A WRITING BY J.H. DE GROOT “DRIEHOEKEN BIJ ONTWERPEN VAN ORNAMENT" AND INTENTION OF ITS PUBLICATION AND CONCEPTION OF THE AUTHOR
}

\author{
濱嵩良実*, 矢代真已** \\ Yoshimi HAMAZAKI and Masaki YASHIRO
}

\begin{abstract}
The aim of this study is, at first, to make clear outline of "Driehoeken bij ontwerpen van ornament" written by J.H.de Groot and, then, to clarify the intention of publication and the conception of the author from the texts in the writing.

As the result, the following matters became clear. 1."Driehoeken bij ontwerpen van ornament" was a joint work with his sister Jacoba, but the contents may say that it is de Groot's own achievement. 2.Contents of the writing seem to be a textbook of basic drafting technique and have unique characteristics of use a set square for designs of ornamentation. 3.As intention of publication, it could be assumed the use to industrial arts education, and, on the other hand, there was the principal objective in the spread of de Groot's own drafting method. 4.De Groot's conception in the work was to ask the world the spread of drafting method to oocupy creation instead of imitation of past styles and natural forms if possible and the propriety.

The drafting method and the examples introduced in the writing had enough contents and persuasive power for suggesting a possibility to a creation, and, in this connection, it became simultaneously clear that possible to point out the reason why the architects of the same period were attracted by the writing.
\end{abstract}

Keywords : Modern Architecture, Holland, J.H.de Groot, H.P.Berlage, Systematic design method, Driehoeken bijontwerpen van ornament 近代建築 オラシダ、J.Hデ・フロート、H.P.ベルラー、体和的設計手法、装飾デザインにおるける三角形

\section{1. はじめに}

建築史家レイナ一・バン八ム（Reiner Bähham）は、『第一機械 時代の理論とデザイン』のなかで、建築家ヘンドリック・ペトルス・ ベルラーへ (Hendrik Petrus Berlage，1856-1934）の業績、とく に「アムステルダム証券取引所 (koopmansburs te Amsterdam, 1903)」の造形の特質について触れて、ベルラーへの「仕事の大部 分はこの比例のシステム (proportional system)」に捧げられてい る、としている。これはベルラーへが同建築の設計に際して用いた $5: 8$ という比例のエジプト三角形による体系的な設計手法を指した 言説である【図一1】。そし、この「比例のシステム」に関わる問 題には、ベルラーへのみならず、同時代のアムステルダムの建築家 の多くが夢中になっていた、とも述べている1)。

こうした設計手法の先駆的研究者として、ベルラーへは当時、建 築家カレル・ペトルス・コルネリス・デ・バーゼル (Karel Petrus Cornelis de Bazel, 1869-1923)、建築家ヨハネス・ルドフィクス・ マチュー・ラウヴェリクス (Johannes Ludvicus Mathieu Lauweriks，1864-1932)、そして教育者で理論家であったヤン・へ ッセル・デ・フロート（Jan Hessel de Groot，1865-1932）の名前 を挙げている2)。特にデ・フロートの理論について、ベルラーへは、

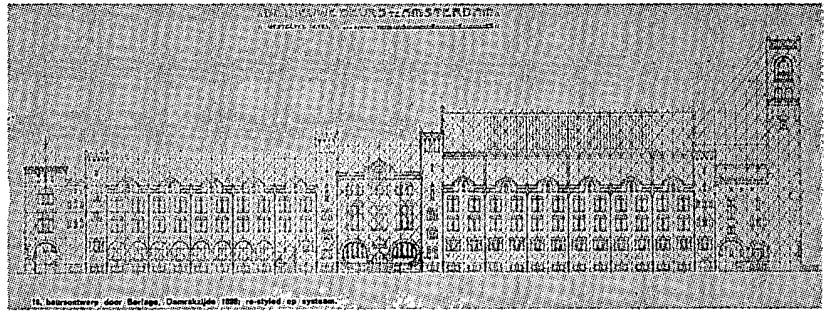

H.P.ベルラー、「アムステルダム株式取引所立面図小、出典; Tummers, NHM,
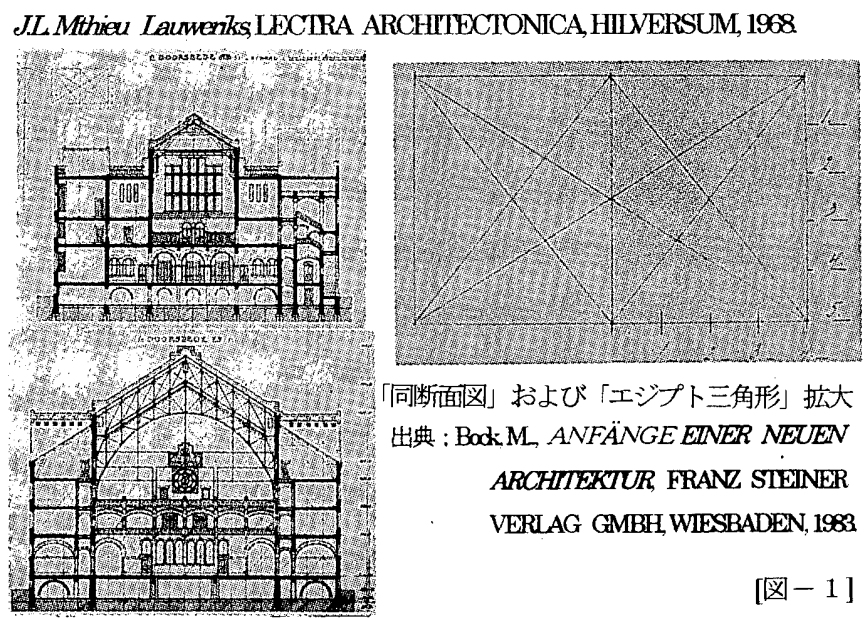

「同断面図」および「エジプト三角形」拡大 出典 : Bodk M ANFÄNGE EINER NEUEN ARCHTEKTUR, FRAN STEINER VERLAG GMBH, WIESBADEN, 1983

[図-1]
* 日本大学短期大学部建設学科 非常勤講師 - 博士 (工学)

** 千葉工業大学工業デザイン学科 非常勤講師・博士 (工学)
Lecturer, Dept. of Construction, Junior College of Nihon University, Dr. Eng. Lecturer, Dept. of Industrial Design, Chiba Institute of Technology, Dr. Eng. 
「近代の比例理論に注目すべき成果をもたらす」と評価し、自らも デ・フロートの理論に従って仕事を進めてきたことを述心、さらに 「デ・フロートに私淑している」、との言説も後に残している3゙

ところで、そのデ・フロートの主著のひとつとされる『装飾デザ インにおける三角形 (Driehœeken bij ontwerpen van ornament, 1896)』は、オランダの装飾芸術の方向性を決定付けた著作である といわれてきた。そして同著作の影響は装飾芸術の領域に留まらず、 建築界にも及び、ベルラーへ以外にも、アムステルダム派の建築家 として知られるミシェル・デ・クレルク (Michel de Klerk, 18841923）らへの影響なども指摘されている4)。また特に同著作は、前 記の「比例のシステム」の普及という問題と媣く関連しており、し たがってオランダ近代建築の勃興期の詳細を考察する際、決して無 視することのできない重要な文献であると考えられる。

ところが、『装飾デザインにおける三角形』の具体的内容について またオランダ近代建築史といら枠組みにおける同著作の意義につい ては、必ずしも明確にされているとは言い難い。

そこで本稿では、デ・フロートの『装飾デザインにおける三角形』 のオランダ近代建築史における意義の検証の前提作業として、同著 作の構成、そして具体的内容について考察する。その上で、同時に 同著の出版の意図、およひ著者の構想について、明らかにしたい。

\section{2.『装飾デザインにおける三角形』の著者および形式と構成 ${ }^{5)}$}

デ・フロートの著作とされる『装飾デザインにおける三角形』は、 後述するように、実際は、姉ヤコバ (Jacoba M. de Groot, 生没年不 詳）との共著である ${ }^{6)}$ 。1896 年 10 月の出版で、A-5版をひとまわ り小さくしたサイズの、白紙頁などを含めて全 92 頁という体裁で あり、いわば小冊子の如きものといってよい。青色の背表紙で、赤 と黒の二色刷りの表紙は、後述する同書の内容を象徴する装丁とな つている【図-2】。3頁目に当たる屝には、同書名の下に、サブタ

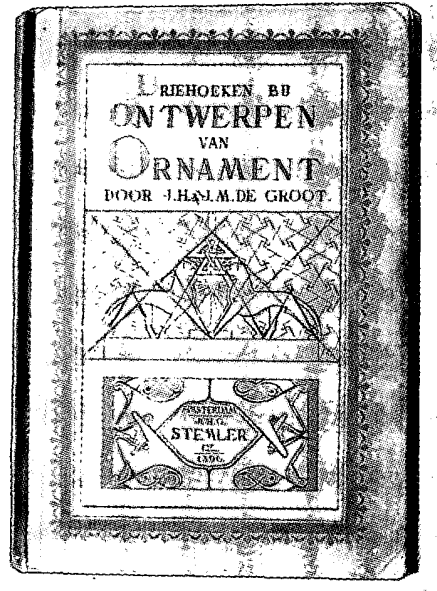

D RIEHOER TN

【図-2】

『装锦デザインにおける三角形』 表紙 AH STERDAS, tog

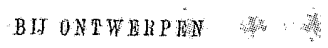

จax

$0 \mathrm{R} N \mathrm{~N} M \mathrm{E} N \mathrm{~N}$

VOOR ZESFSTUDIE GN VOOR SCHOLENS

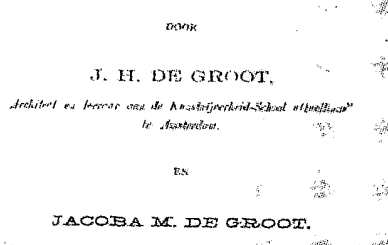

.

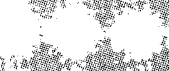

【図 $-3 】$

『装飾デザインにおける三角形』の屝
イトルとして「独習者、指導教官のために」とある。その下には筆 者ヤン・ヘッセル・デ・フロートの名前と、「建築家」および「アム ステルダムのクエリヌスエ芸学校 (1879 年設立) の教師」という 2 つの肩書きが記されている7 の下に記されているが、有書きは明記されていない【図一-3】。

同書は全 5 節、寸なわち、「前言」(計 2 頁)、「目次」(計 2 頁)、 「序論」(計 3 頁)、「図版解説」(計 20 頁)、そして図版 (52 点)」 (計 52 頁) という構成になっている。このうち「目次」を除くす ベての文章の末尾部分には、ヤン・ヘッセル・デ・フロートとの記 名が付されている。したがって、姉のヤコバとの共著となってはい るものの、事実上、本小冊子はほとんどヤン・ヘッセル・デ・フロ 一ト単独の執筆によるものであったと考えてよい。つまり主著者は、 ヤン・ヘッセル・デ・フロートであり、姉ヤコバの関与は図版制作 の協力程度であったと推測される。

\section{3.「前言」にみるデ・フロートの言説8)}

『装飾デザインにおける三角形』出版の意図、さらに主著者であ るヤン・ヘッセル・デ・フロート（以下、デ・フロートと略記）の 同著作執筆の構想を明らかにするために、まず、同著「前言」にみ るデ・フロートの言説を順を追って見ていきたい。

「前言」は「過去数年間、わたしはまったくわたし自身のための研 究を行ってきた」という言葉で始まっている。デ・フロートはこの 研究を「製図と意压の領域における確たる事実を探求する作業」と 位置づけている。作業は「決して借用する（過去に戻る）ことなく、 つねに前進し続ける」ように行ったという。そしてデ・フロートの 達した結論は以下の事柄に対するデ・フロート自身の無知の認識で あったと述べられている。それはすなわち、製図というものは非常 に単純なものであり、意匠は明解なかたちで現われ、製図は実際、 しばしばそのように行われ、また意厈はそのように表現されること が必然とされてきた」こと、である。デ・フロートのこうした認識 は、同時に、「過去の様式時代においては実際に規則 (weten) とさ れていた、感情や偶然に基づく多くのものを、数学的に位置づける ことを満足させる」ものであった、という。

ここでデ・フロートが示唆する製図法に関連して、「前言」では、 それが「かつては明確に意識されてはいたが、僅かにしか考慮され てこなかったために次第に忘れ去られ、失われたものとなっていた のか、あい忆うした方法自体がいわば奥義（atelier-geheim） として伝承されてきたのか、という問題にも言及してはいるが、 デ・フロートはこうした問題に対して、明確な答えを提示すること を避けている。ただ、いずれにしても単純な事実を複雑に説明する ことは「愚行」であり、事実の「過大評価、あるいは逆に「軽視」に 繫がる危険性を孕むとのみ指摘する。その上で、(1)諸フォルムの簡 単な現出とその確たる事例の明示、(2)装飾的構成における統一性を 確立するための手法の提示、以上 2 点を目的に、多角的な視点によ る考察を重ねた結果として、デ・フロートは、姉のヤコバの助けを 借りて、線装飾、植物装飾、動物装飾、そして文字（タイポグラフ イー)といった一連の図版を作成したことを記述し、「前言」を締め 括っている。

続いて「序論」の内容を辿ってみたい。 
【表-1】『装飾デザインにおける三角形』図版一覧

\begin{tabular}{|c|c|c|c|}
\hline 图版番号 & 图版多イル & 作成者 & 具体的内容 \\
\hline 1 & 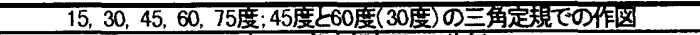 & $M$ & 2枚の三角定規こよるさまさまな角度の作图 \\
\hline 2 & 45 度の三角定規亡月の8分曾 & $\bar{M}$ & 45度の三角定規の便用法と円の8分割方法 \\
\hline 3 & 60度の三角形と6角形 & $M$ & 60度三角定規の使用と正三角形の4分割、六角形 \\
\hline 4 & 60度のシステムと30度のジステム & $M$ & 正三角形(60度)格子ट60度-30度グリドの图 \\
\hline 5 & 鱼状琣䫁こおける60度の角度 & $M$ & 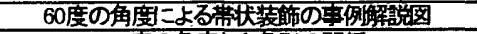 \\
\hline 6 & 60度と30度の三角形老用いた & $M$ & 30度の角度と六角形の関係 \\
\hline 7 & 带状琶䞂二おける30度の角度 & $M$ & 30度の角廈こよる带状装飾の作图法 \\
\hline 8 & 60 度の対奐線老持つ四奥形 & $M$ & 西解形卆内 $1=60(30)$ 度の対角線㞭引K作図法 \\
\hline 9 & 30度と60度の角度。円の3分㓷、6、12分剽 & $M$ & 60-30度三角定規二よる円の3，6，12分劕法図解 \\
\hline 10 & 30-60度の角度によつて作られた图 & M & 30-60度の角度奇使つた作图の方法と事例 \\
\hline 11 & 蒂状挔瞋二お1十る30度と60度 & $M$ & 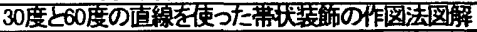 \\
\hline 12 & 30度と60度の線の角度によつて梅成された縁取り & $M$ & 30度と60度の直線乥使つた緣取り垡䀢作图法图解 \\
\hline 13 & 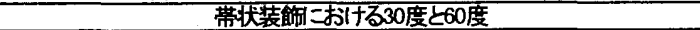 & $\mathrm{M}$ & 60度の三角定規使用の带状装飾の作图法と事例 \\
\hline 14 & 三位一体 30-60度の三角定規二よる線の分慗( $(2,3,4,6,8,9,12$ 分割) & $M$ & 3要素の統一と要公害小方法の图解 \\
\hline 15 & 30度と60度のシステムによる波形 & $M$ & 波形裴臫の作图法莡图解 \\
\hline 16 & 30度と60度の触の線による緣取り & $M$ & 30-60度の角度老使つt-緑取し裝飾の事例 \\
\hline 17 & 装飾二応用された =60度のシステム & $\mathrm{B}$ & 正三角形格子による平面装飾の車例 \\
\hline 18 & 装飾二応用された & $\mathrm{B}$ & 60-120度格子こよる平面装飾の事例 \\
\hline 19 & 60度のシステムのよる木版画 & $\mathrm{B}$ & 正方形格子による木版画作品の事例 \\
\hline 20 & 2枚の三角定規の明解な使い万。15度と75度 & $\mathrm{H}$ & 2校の三角定規で15、75度を得る作図法と庶用 \\
\hline 21 & 2枚の三角定規の明解な使い方。円の24分图 & $\mathrm{H}$ & 2枚の三角定規二よる円の24分古法图解 \\
\hline 22 & 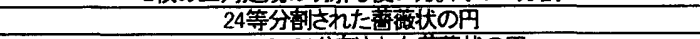 & $\mathrm{B}$ & 円の24分割図解 \\
\hline 23 & 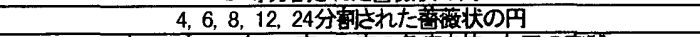 & $\mathrm{H}$ & 円の分翻法の図解 \\
\hline 24 & 15度、30度、45度、60度、75度の角度老使つt=円の実钱 & $\mathrm{H}$ & 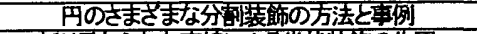 \\
\hline 25 & 二重のリえ厶の带 & $\mathrm{H}$ & 折り重ねられた直線こよる带犾装敗の作图 \\
\hline 26 & 二重のリスムの帯 & $\mathrm{H}$ & 同上 \\
\hline 27 & 正方形とその中の30度と60度 & $\mathrm{H}$ & 正方形の分醞装飾法の図解 \\
\hline 28 & 四解とその什 15 度と75度 & $\mathrm{H}$ & 同上 \\
\hline 29 & 四角形と15度、30度、45度、60度、75度という角度 & $\mathrm{H}$ & 同上およひ事例 \\
\hline 30 & 同一のシステムによる四角形の装飾 & $\mathrm{H}$ & 同上 \\
\hline 31 & 15度、30度、45度、60度、75度のシステムによる装䀢 & $\mathrm{H}$ & 装飾の車例 \\
\hline 32 & 三角形定䫏二よる線の分割 $(5 ， 7 ， 13 ， 14 ， 15$ 分割) & $\mathrm{H}$ & 三角定規死使った線(長方形)の分雷法図解 \\
\hline 33 & さまざまなシステムによる文字形態 & $\mathrm{H}$ & 多イホクラフィーの作成図解 \\
\hline 34 & 同一システムによる大文字のアルファベット & $\mathrm{H}$ & 同ーシスステムムよるアルプベットの作図法图解 \\
\hline 35 & あるタイプの装飾文字によるブジックのアルファベット & $\mathrm{H}$ & ゴジソク軎体の作图法と事例 \\
\hline 36 & 内部 $=15 、 30 、 45 、 60 、 75$ 角度て装飾されたフォルムを持つ正三角形 & $\mathrm{H}$ & 正三角形を基二した菬飾の作図之実例 \\
\hline 37 & 内部 $=15,30 、 45 、 60 、 75$ 度の角度て装飾されたフォルムを持つ正方形 & $\mathrm{H}$ & 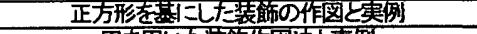 \\
\hline 38 & 内部に $=15 、 30 、 45 、 60 、 75$ 度の角度て装飾されたフォルムを持つ中形 & $\mathrm{H}$ & 㱝用いた装的布作图法と事例 \\
\hline 39 & 三角定規乥用いて描いた棝物昰旍の枝 & $\mathrm{H}$ & 植物文様装飾の作図法と実例 \\
\hline 40 & 三角定規老用いて描いた精維な枝 & $\mathrm{H}$ & 同上 \\
\hline 41 & 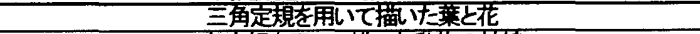 & $H$ & 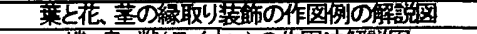 \\
\hline 42 & 三角定規老用いて搐いた動物の軏楾 & $\mathrm{H}$ & 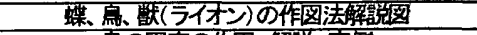 \\
\hline 43 & 三角定規老利用した虑の俥線 & $\mathrm{H}$ & 鳥の图案の作図、解説 事例 \\
\hline 44 & 三角定規苯用いて搐いた人体图 & $\mathrm{H}$ & 人体の図宩作図解説 \\
\hline 45 & 三角定規老用いた、應用された装飾 & $\mathrm{H}$ & 态用事例走揭戴している \\
\hline 46 & 学生の設䚺 & $L$ & 植物縁取り琶飾(BW) \\
\hline 47 & 学生の暿㖕 & $L$ & 同上(BW) \\
\hline 48 & 学生の設觔 & $\mathrm{L}$ & 同上(BW) \\
\hline 49 & 学生の設話 & L & 同上(BW) \\
\hline 50 & 学生の設塥 & L & 幾何学文稼の給取り装部実例(C) \\
\hline 51 & 学生の設諡 & $L$ & 同上 $(\mathrm{C})$ \\
\hline 52 & 学生の設神 & $\mathrm{L}$ & 同上(C) \\
\hline
\end{tabular}

\section{4. 「序覦」の内容について}

「序論」において、デ・フロートは適宜、図版（図版一覧を【表 -1】に示す) の参照を求めながら、前節て触れた 2 点の目的を達 成す心゙く、自らの製図法の解説を行っている。

まず「序論」冒頭で、デ・フロートは自らの紹介しようとする製 図法を「小作業（werkje）」と呼ぶ。「小作業」には「45 度および 60 度 (30 度) の三角定規を補助的な道具として用いたことを述 べる。そして、それらの三角定規を用いることで、「15 度一 45 度一 60 度一75 度の角度が導き出せる」ことを説明し、図版 1 の参照を 求める【図-4】。そして2枚の三角定規を使って行われたこの「小 作業」の目的が「製図法を確立すること小、さらにその製図法により 作成された図版の「諸事例は如何なる歴史的様式も借用していない こと、を強調する。

デ・フロートの構想 さらに具体的にいえば、創造という行為を デ・フロートがいかに捉えていたかを知る意味で、「序論」の次の言 説は重要であろう。
【図-4】

『装飾デザインにおける三角形』 の図版 $1 ； 15,30,45,60,75$ 度 ; 45 度と 60 度 (30 度) の三角定 での作図

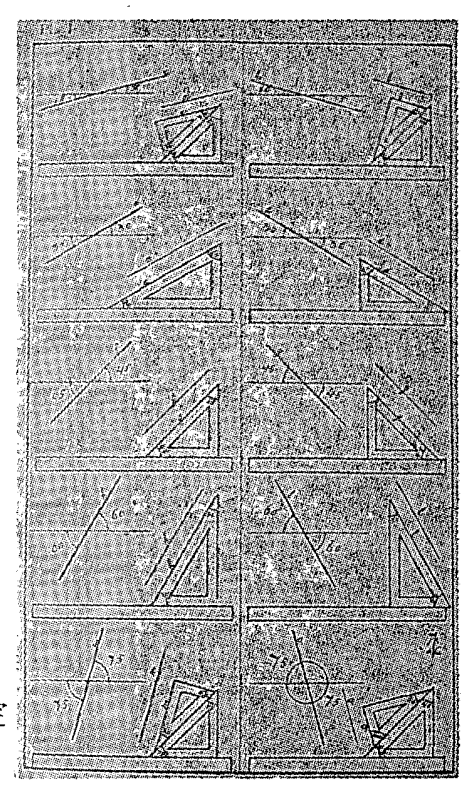




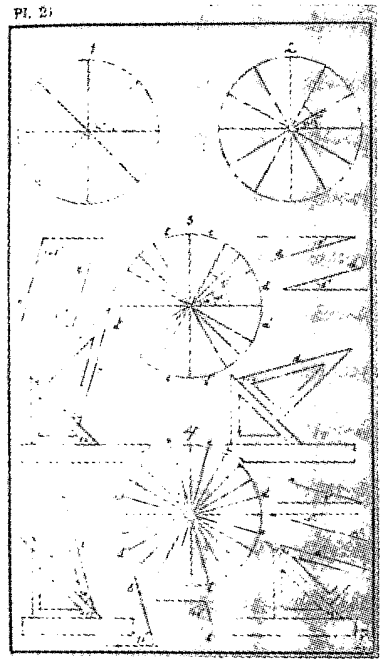

【図-5】図版21「2枚の三角定規の

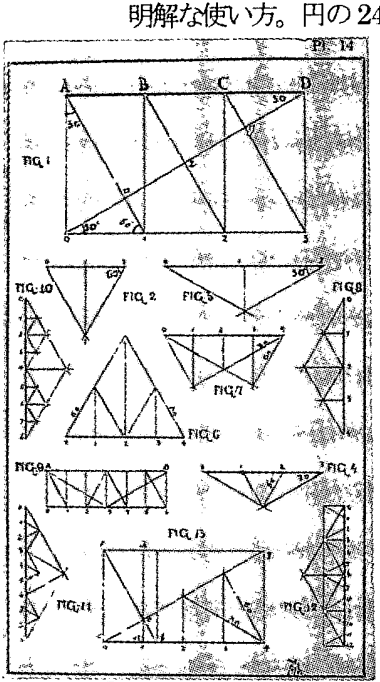

《図-9】図版 14

三位一体、30-60 度の三角定規による線の分割」

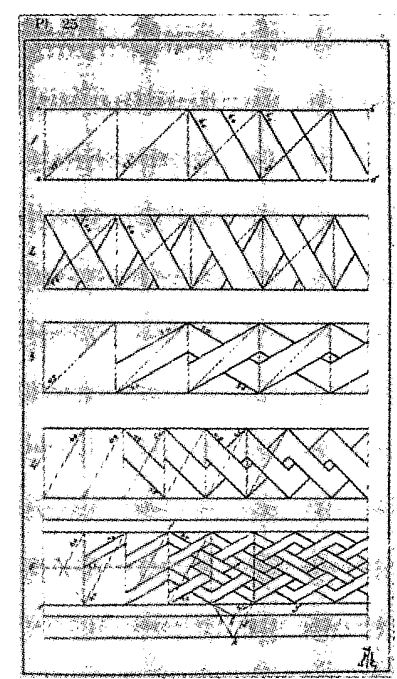

『図-6】図版 $25 \mid$ 二重のリズムの帯」
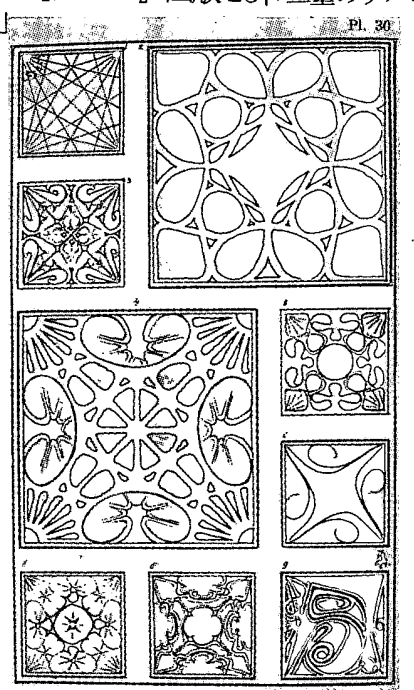

】図-10】园版 30

「同一システムによる四角形の装飾

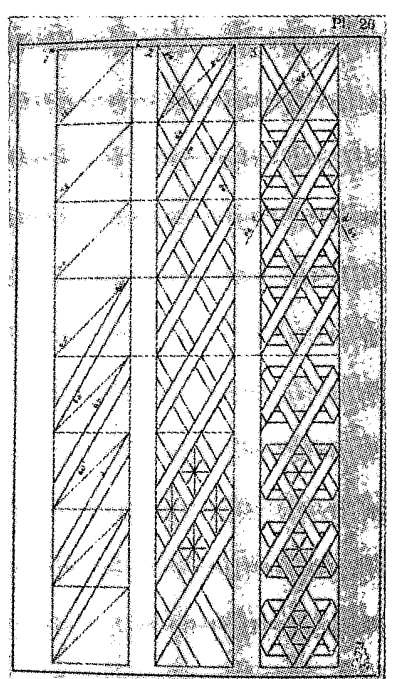

《図-7】娄版 26

二重のリズムの帯」

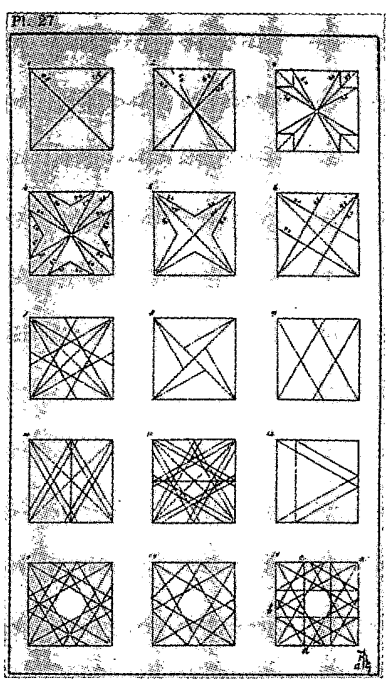

『図-8】园版 27

正方形とそのなかの 30 度と60 度」

平面装飾の意匠というものは、純粋に平面に分割することである。

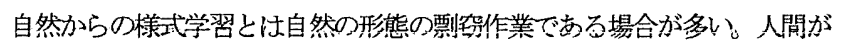
自然から拝借できるのは、たいてい忧うしたものではないのである。

創造に至る者は、直接的な剽䆛を認めることはないであろう。

われわれは事実に則ってモチーフを育まねばならない。それは人間の装飾 への意志であって、そのためにすべてが推し進められる。そしてその㷌結と しての、平面構成が必要とされるのである。

さらに続けて、デ・フロートは自らの製図法の特徵を次のように論 を展開寸る。

諸図版の作成方法は、通常の力法とは逆転されたものとなっている。一般 に、ほとんどの場合は、あるフォルムを自然の形態と捉え、そしてそれ自身 を目的として考える。つまり、はじめにモチーフありきで、リズムは二義的 に捉えられている。

この小作業しおいては、全体としての整合性を有する統一的なもろもろの 線が第一義とされる。つまり、はじめにリズムありきで、モチーフは二義的 なものとされる。換言すれば、モチーフはリズムに変換されるのである。

また「序論」のなかで繰り返して、デ。フロートは自らの製図法

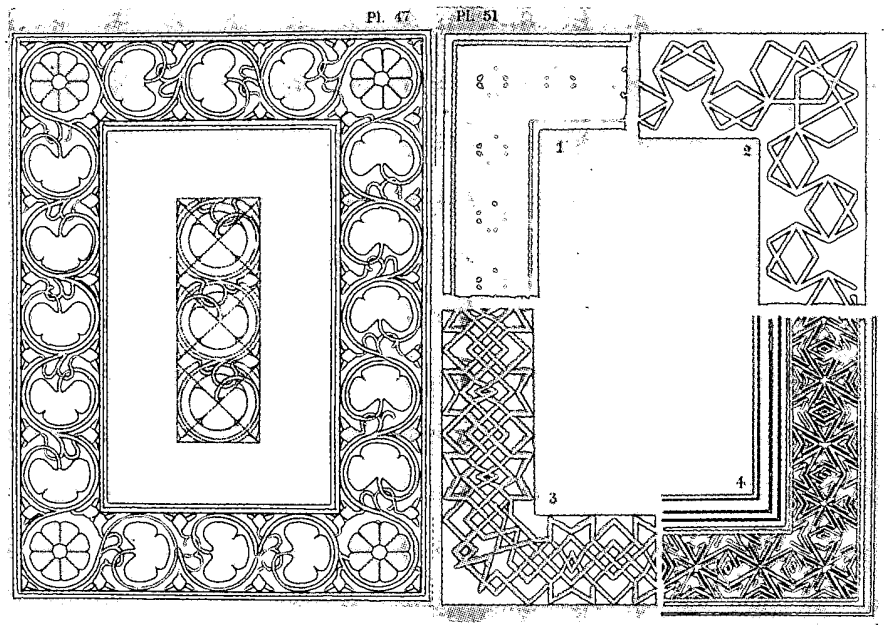

が「自然の形態の剽窃」ではないことを強調しながら、その新しさ については次のように主張している。すなるち、「この著の新しさ は製図板上での三角定規の、全体を通じての利用にある」と。した がって、そうであるが牞えに「統一性」は必然的に「保証さされ、統 一性の欠如の心配も無用」であり、さらに「それ以上の手段は危険 をもたらすことになる」とさえいう。

個別的な、やや仔細な図版の説明の後、「前言」の内容を繰り返す かのように、次のような言葉で「序論」は閉じられている。図版 21

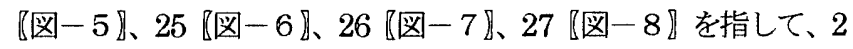
枚の三角定規から得られるさまざまな角度の方向性を相互的に取り 込んで利用することは、「装飾に対するわれわれの力を大きなもの とさせる」。そして「それ忧打のの様式時代において、幾度か行 われたものに違いないが、「しかし我々の時代においては、それは 規則の一つに過ぎず、あるいは直視されていないのか、あるいは過 小評価されている」との解釈も示している。そして、「これについて は図版25のテキストを見よ」との指示を出している。

指示通り、図版 25 の図版解説を見てみると、2林の三角定規から 得られるいくつかの角度をもつた直線を組み合わせることで、さま ざまな装飾のヴァリエーションを導き出せることが説明されている。 そしてそこでは、製図法の応用の充分な可能性が唱えられ、また実 
際に同様の手法で、装飾を作成することを読者に促してもいる。

\section{5.「図版解説、および「図版、について}

「図版解説」は、タイトルそのままに、後に続く「図版」の内容 の解説である。図版解説」の中には、特に製図法に関する理念的な 部分のデ・フロート自身の主張は見出せない。興味深いのは、いく つかの図版の具体的な作図法の解説のあとに、作図上の留意点を列 記したり、また示された手順に従って実際に作四寸ることを読者に 促し、解説した作図法を利用して誢者に事例と異なるヴァリエーシ ヨンを作成してみよ、との指示があることである。実際、同著のサ ブ・タイトルにある独習者、指導教官のために」という言葉通り に、かなり丁寧な作図法の解説が展開されていること、上記の図版 解説にみる特徽から、いわば教則本的な、あるいは教科書的な性格 の非常に強い著作であった、といらことができる。

同著作には、全部で 52 の図版分揭載されている。明確にそれぞ れの図版の性格を分類することは困難だが、大まか炕言って、この うちの 11 (図版 $1 ， 2 ， 3 ， 6 ， 9 ， 14 ， 20 ， 21 ２ 2 ， 23 ， 32$ ) が基本的な三角定規の使用法の説明や線分、円、四角形などの三角 形による分割の解説図であり【図ー9】残りの図版は実際に装飾の 創出過程（線の構成による装飾、植物や動物のフォルムの装飾、文 字などの多様な装飾形態执よびそのヴァリエーション）を示したも の、また完成した装飾作品の事例となっている【図一10】。各図版 には、そのほとんどにデ・フロート (25枚)、あるいはヤコバ（16 枚）の署名があり、作成者が解るようになっている。図版最後の 7 つは、特に学生の作品と明記された扉で区分され、応用実例集とで もいうべき役割を担う部分となっている。これらは、デ・フロート がクエリヌス工芸学校で指導した学生の作品であると考えられる。 なか炕は（このうちの3枚には）着彩を施されたものもある【図一 11)。

\section{6. デ・フロートの著作出版の意図と構想}

デ・フロートが『装飾デザインにおける三角形』を出版した意図、 そして同著作における構想とは、一体如何なるものであったのだろ うか。

既述のように、また実際にその内容を一覧してみても、同著作は やはり専門家を対象とするような複雑て難解な、理論書とはいえな

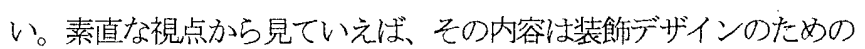
三角定規を使った作図法を基礎から平易に説明していく入門畫的構 成を採った、いわば初学者向けの、まさに教科書的存在であったと いえる。だが、管見では、同著作が出版後に特にクエリヌス工芸学 校で、また他の工芸学校で教科書として使われていたという記録は ない。ただ、同著作出版後、クエリヌス工芸学校では、これを教材 として使用した可能性は非常に高い。実際、1893年頃から、デ・フ ロートがクエリヌス工芸学校で同著作にあるような指導を始めてい たといら記述は残っているからである ${ }^{10)}$ 。また、同書に学生の作品 があることは、その裹付けともならう。したがって、少なからずデ・ フロートが自らの研究成果である三角定規を用いる製図法を自分の 教育活動にお讨る教材として利用し、また他の工芸学校でもそのよ
うに使用されていくことを希望し、目論んでいたという可能性は否 定できず、充分にありえることであったともいうことができる。

ところで、当時のオランダの工芸学校に执ける装飾の製図教育と はいかなるものであったのだろうか。

19 世紀末から 20 世紀という世紀転換期におけるオランダの工芸 学校教育の具体的な内容については、たとえばオランダの美術史家 H.H.ペイゼルードーミッセの論文に詳しい ${ }^{11)}$ 。それによれば、そ こでは伝統的に、歴史主義的な様式の彫刻や版画、また自然の造形 を教室に持ち、込み、それを手本に、すなわちモチーフを前にして装 飾をいかばフリーハンドで模写する作業が行われていた【図ー12】。 それは、デ・フロートが「剽拐」と呼ぶ作業に他ならないここれを デ・フロートが、創造行為と峪別していたことは、「前言」の言説と

「序論」の内容から明らかである。つまり、デ・フロートの著作出 版には、そうした旧来の製図教育を改革しようとする意図を読み取 ることができる。

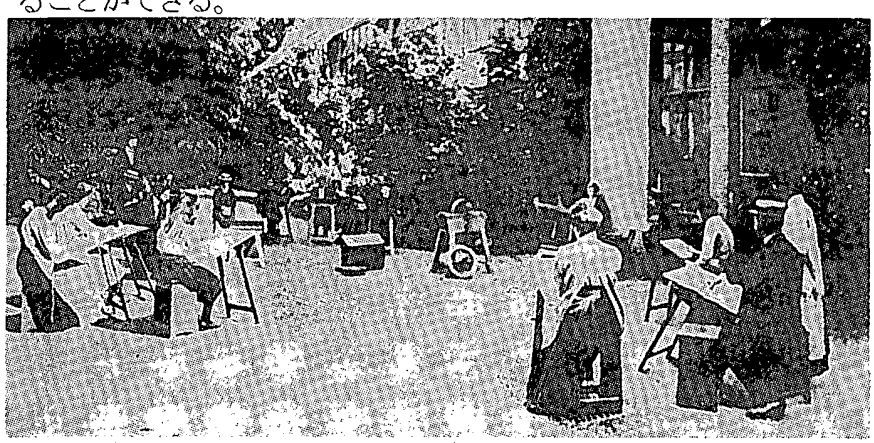

【図-12】ハールレム工芸学校での製図の授業の様子

(1900 年頃)、出典 ; Pijzel-Dommisse,H.H. et al,

Paviljoen Welgelegen 1789-1989, Schuyt\&Co, 1989, p.167

詳細な検討を要寸るゆえに、ここで論じることは控えるねばなるま いが、デ・フロートをこうした方向に導いた要因の一つとして、イ ギリスの工芸運動の影響があったことは指摘できる。デ・フロート の同著作の出版年は、まさにイギリスの工芸運動の波が実際に才ラ ンダ装飾芸術界に押し奇せ始めた時期と重なっているからである。

いずれにしても、デ・フロートのこの著作の出版の意図は、自ら が個人的に進めてきた研究の成果、つまり 1893 年頃から実際に教 育活動でも採り入れてきた平面装飾の製罒法を広く普及すること、 そしてその妥当性を世に問うことにあったと考えられる。

「前言」の言説、そして「序論」の内容、また「図版解説」、図 版」から総合して読み取れるデ・フロートの構想は、以下の 2 点に 集約できよう。

(1) 三角定規による単純な平面装飾の製図法の妥当性の主張と普及

(2) 剽贺ではなく、創造行為の結果としての意匠の実現

前者について言えば、この著作において、デ・フロートは、三角 定規という道具を一貫して利用することで、作図者の染意性がある 程度規定されること、したがって感覚や偶然といった主観性や偶然 性によるので汭い、より客観的な意匠を導き出すき出すことが可 能であること、またそれは三角定規（時には円、正方形）により生 み出される触度にって限定されるために、「全体としての整合性 を有する」統一的な意匠が可能であること、を主張している。これ は後者の構想人と慗がっていく。

三角定規を一貫して利用する製図法から得られた意匠は、統一性 
が幾何学によって保証される。そしてそれ過去の歴史主義的様式 モチーフ、あるい性自然の造形をモチーフにして行われていた模做 行為としてのデザインとは異なる。つまりデ・フロートは自らの製 図法を、創造への可能性を持つ、創造の基礎と措定していたという ことができる。デ・フロートがこの著作において展開した議論は、 平面装飾の製図の領域に限られるが、モチ一フといら形式あるい は形態の模做、つまり剽穷を、リズムというより客観的な概念を導 入することによって、飤造という行為へと変換させていこうとして いたという点で、注目すべきところがあったといえるだろう。

こうした点にこそ、同時代の周囲にいた建築家たちもが高い関心 を寄せた同著作の革新性がある。実際、同著作はそれ相当の内容と 説得力を有していた。

\section{まとめ}

以上、デ・フロートの著作『装飾デザインにおける三角形』の構 成、具体的内容、また同著作の出版の意図、著者の構想などについ て検討を行ってきたが、以下に明らかになった点をまとめておきた い。

(1)デ・フロート単独の著作などともいわれてきた同著作は姉ヤコバ との共著であった。姉の関与は図版作成程度で事実上は、デ・フ ロート単独の著作といってもよい内容であったこと。

(2)著作の具体的な構成と内容については、デ・フロートが個人的に 研究を進めてきた三角定規を一貫して用いた簡単な製図法を紹 介するかたちを採り、決して難解な理論書などではなく、どちら かといえば初学者向けの簡単な教則本、あるいは教科書的な構成 と内容であったこと。

(3)同著作出版の意図の一つは、自らの教育活動に利用しようと考 えていた可能性もあり、また自らの唱える製図法を広く普及させ ようというものであったと考えられること。

(4)著者の構想としては、過去の歷史主義的様式の模做、あるいは自 然の形態からの剽铂行為に終始する傾向にあった平面の装飾芸 術の意匠を、また当時の伝統的な工芸教育の変革を、リズムとい う概念を導入し、感覚や偶然に頼らない、より客観的な次元での 創造行為として実現させ、いわば革新的な工芸教育を可能ならし めようとするところがあったとも考えられ、また自らの製図法の 妥当性、さらにはその有効性を世減うことを目的としていたと 考えられること。

同著作にみる模做とは哕別された創造の可能性の主張こそが、周 囲の建築家をして、高い関心を寄せさせた理由であり、実際、同著 作はそれだけの内容と説得力があったことも同時に確認できた。 た、こうした同著の内容と構想は、後のオランダ近代建築の展開を 先んずる革新的なものであったということも可能である。

なお、これまで見てきたテ・フロートの同著作の反響が、いが して建築の領域に及んでいったのか、また実際にベルラーへら当時 の建築家たちにどのようなかたちでそれは影響を及ぼしていったの かといら点については、雑誌上での言説、またデ。フロートが提示 した製図法に対する見解などが残されており、それらを詳細に検討、
分析する必要がある。また、デ・フロートのこうした著作の内容、 そこにみられる構想は、本論でも示唆したように、イギリスの工芸 運動との関係を無視して論ずることはできない。記の事柄の検証 については稿を改めて論じたい。

1) Banham,R., Theory and Design in the First Machine Age, The MIT Press Cambridge,Massachusetts,Second Edition, 1989,p.142. (石原達二ほ訲、『第一 機械時代の理侖とデザイン』、鹿島出版会、1976 年、pp.203-205.)

2) Banham, R,op.cit,p. 142. (丰臤書 p.204.)、Singehberg,P, H.P.BERLAGE DEEA AND STYLE, HAENT JENS DEKKER\&GUMBERT,UTRECHT, 1972,pp.109, Tummers, N.H.M, Der Hagener Impuls, KG Hagen, 1972, pp.19-20.を参照した。 1898 年の 証券取引所」に関する諘演での言集で、雑誌 Bouwkundig Weekblad, 1898, p.3、に掍载。

3) Slebos, J.C., Grondslagen voor aesthetiek en stijl,Amsterdam, 1939, p.5.

4) Frank,S.S.,Michel de Klerk 18841923 An Architect of Amsterdam School,UMI RESEARCH PRESS,MICHIGAN, 1984,pp.29-30,Wit,W.D. et al, THE AMSTERDAM SCHOOLMTT PRFSS ,CAMBRIDGE, 1983 , pp.82-86, Fanelli,G.,Moderne architectuur in Nederland 1900-1940,Staatsuitgeverij,'s-Gravenhage, 1978,pp.29-35.t 参照した。

5) J.H.\&J.M. de Groot, Driehoeken bijontwerpen van ornament, JOH.G.STEMLER

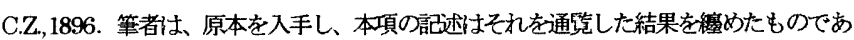
る。な抎 筆者所有の同著には著者ヤン・ヘッセル・デ・フロート、ヤコ值筆の署名、 その下に 157 とのナンバリングがある。また建築家ヤン・スタイト (Jan Stuyt，1868-

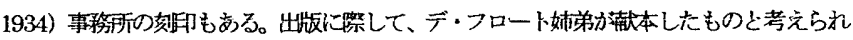
る。

6）たとえば、Zoon, V.C., Auf dem Wege zu einer monumentalen "Nieuwe Kunst"-Die Proportionslehre und Entwurftheorie von J.LMathieu Lauweriks, in ; J.LM Lauweriks, Kaiser Wilhelm Museum, 1987, p.35.などのようにここの著作よデ・フロー トの単独執簕であるかのように語られることも多い。

7）デ・フロートは クエリヌス工芸学校の卒業生で、1888年9月から 1917年 1 月ま で、クエリヌス工芸学校て教鞭を執っている。建栄家としての業績土筆者の知る限りでは

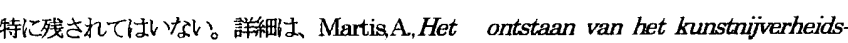
onderwijs in Nederland en de geschiednis van Quellinusschool te Amsterdam (1879 1924), in ; Nederlandse Kunsthistorische Jaarboek 3a１979, pp.126-128. を参照 8）本節中の引用忖べて、J.H.\&J.M de Groot, Driehoeken bij ontwerpen van ornament, JOH.G.STEMLERC.Z,1896., pp.5-6.の「前言」からのものである。

9）本節中の引用忖ずて、J.H.\&J.M de Groot, Driehoeken bij ontwerpen van ornament, JOH.G.STEMLER C.Z, 1896., pp.9-11.の[前言」からのものである。

10) Martis $\mathrm{A}$,ibid

11) Pijzel-Dommisse, H.H., Het museum en de school voor kunstnijverheid in periode 1877-1926, in; Pavijoen Welegelegen 17891989,Schuyt\&Co., 1989.,pp.151-172. を势 した。

（2000年 7 月 4 日原稿受理，2001年 2 月 27 日採用決定） 